\title{
The Dutch Reformed Church as a prominent established South African church: In transition towards the 21st century
}

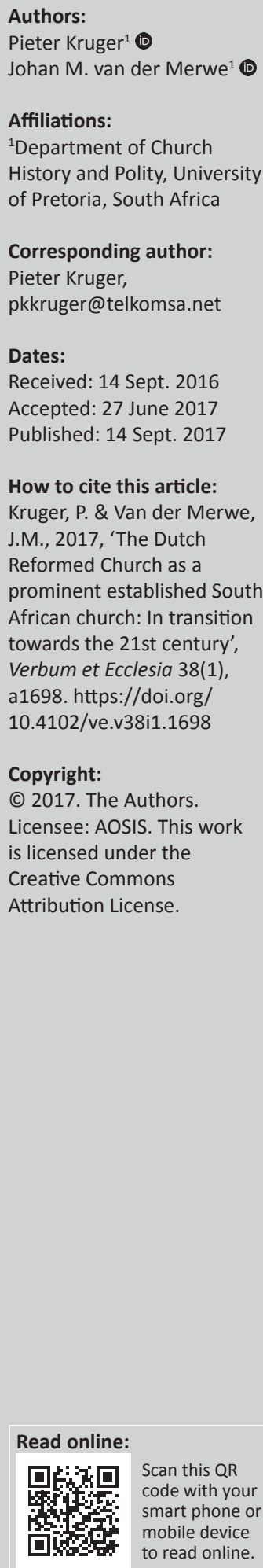

\begin{abstract}
The Dutch Reformed Church (Nederduitse Gereformeerde Kerk) is in transition because of the influences of the more recent South African epochs of democratisation, Africanisation and globalisation. The histories of these epochs extend over more than 20 years and have had a significant influence on the church. The Dutch Reformed (DR) Church changed institutionally because its place and influence within society changed considerably as a result of political and social transformation since 1994. The ongoing process of Africanisation that accompanies these transformations brings certain reactions to the bosom of the church via the experiences of its members. Most are Afrikaners being more inclined to westernised social frames of reference. Ironically, these people are more susceptible to the effects of globalisation, especially secularisation, which transposes the religious set-up of the DR Church into an open and individuated system. These developments pose major challenges to the DR Church in the sense that it has to reconsider how it approaches society, what it can contribute to the ecumenical church, why it is necessary to reflect on its denominational identity and what its academic, theological endeavours in these regards entail.

Intradisciplinary and/or interdisciplinary implications: This article has an interdisciplinary scope because the multiplicity of the present-day calls for interdisciplinary academic reflection. For the purpose of this article, Church Historiography helps to systemise recent ecclesiastical developments within the DR Church. To clarify the influences of these developments on the DR Church, sociological premises are incorporated to describe them within a broader social context. References to the conducted empirical study serve to explain respondents' (members of the DR Church) social and religious constructs regarding these ecclesiastical and sociological phenomena.
\end{abstract}

\section{Introduction}

Considering the question of where we come from, Moltmann (1989:327) proposes that history has two dimensions: firstly, the historical event as it actually occurred, and secondly, the description and reconstruction of that event. The latter is a historiographic process through which the causal nexus of historical events and their impact on a specific society or institution become clear. For the purpose of this article, such a historiographic process will be used in reflecting on the history of the Dutch Reformed Church in South Africa since 1994.

\section{The Dutch Reformed Church as a prominent established South African church}

The second article of the Dutch Reformed Church's constitution states that the church is called by God Triune to participate in God's mission to the world (Die Kerkorde van die Nederduitse Gereformeerde Kerk 2015:1). As such, the Dutch Reformed Church has been a prominent South African institution deeply embedded in the history of South Africa. Significant events throughout its history of more than 350 years can be noted. The year 1652 is the terminus a quo, marking its appearance as a Protestant church with a strong Calvinistic spirituality on South African soil. The year 1824 is the terminus ad quem when the church was consolidated in an independent synodical relation (Van der Watt 1989:i-ii). More recently, the year 1994, the year in which the African National Congress took political office, can be described as a terminus transitus which had a tremendous effect by setting the South African society and the DR Church as an integral part of it into transition. 


\section{The Dutch Reformed Church: In transition because of the history of political and social transformation in South Africa since 1994}

The DR Church whose members are predominantly Afrikaners was deeply affected by the political transition after 1994. Prof. J.A. Heyns mentioned this fact during his speech at the church's General Synod of October 1994. According to him, radical political and social changes were the source of collective social anxiety and insecurity and of the loss of purpose amongst the church's members (Handelinge van die Algemene Sinode 1994:530). Why would that have been the case? To begin with, they lost their political power (Durand 2002:51). And as a result, the year 1994 was a shock to the Afrikaner in general according to Schreuder (2002:226). But the relevant question is whether this collective reaction is still prevalent after more than two decades.

To understand those initial reactions, Esterhuyse (2001:187) argues that the pre-1994 apartheid ideology created a closed worldview with limited perspective for most Afrikaners. Central to the ideology was the idea that humankind could be categorised into homogene racial groups that existed segregated along the racial divide. Consequently, in the South African society, the apartheid discourse was consolidated in a system of separate institutionalised structures and practices for different racial groups (Van der Walt 1999:25), in which white South Africans were privileged. This led to a legacy of social disintegration, non-development and disadvantage for the larger population who became more agitated in their struggle against apartheid (Wessels 2001:256). After the realisation of a unitary, democratic state in 1994, apartheid as part of the Afrikaner's worldview was discredited and all measures were taken to dismantle it. With that came the awareness that racial groups were deeply divided and estranged. In the wake of what the future held the feelings of collective social anxiety and insecurity amongst members of the DR Church make perfect sense.

Furthermore, the apartheid ideology with its strong anthropological arguments for racial group differentiation became intertwined with the Christian faith (Heuvel 1999:28). This happened because the apartheid worldview was sanctioned by the Afrikaans churches (the DR Church included) - and as such, it settled in the psyche of most Afrikaners. The civil religion that thus developed made it difficult to distinguish the religious culture from the political and intellectual culture (Martin 2005:55). Even after the DR Church formally dissociated itself from the apartheid ideology and practices at its General Synod of 1990 in Bloemfontein, recent empirical research ${ }^{1}$ has

1.Empirical research was undertaken in 2013 in conjunction with the Department Statistics at the University of Pretoria as part of the author's (P Kruger) PhD studies. It was conducted through questionnaire responses in 50 congregations of the Highveld and Eastern synodical areas of the DR Church, selected by comple Highveld and Eastern synodical areas of the DR Church, selected by complex stratified sampling. 1186 respondents took part in the research. The responses to the questions in the data set were consolidated into 18 concepts of which the outcomes explained the social, personal and religious identities of members of the DR Church and their collective influence on the DR Church as institution. The method for statistical analysis used by the Department Statistics is described in (Cody \& Smith 2006). shown that older members of the DR Church take longer to part with their internalised apartheid ideas because they were influenced by it more than younger generations.

Moreover, the political and social transformation process in South Africa was revolutionary rather than evolutionary (Du Toit 1999:2). Regarding this, Esterhuyse (2001:189) explains that a strategy that brings about radical transformation of a political dispensation or a social institution creates conflict and uncertainty. Sociopolitical transformation is unsettling for those loyal to a previous order of things. Discontinuity foments resistance to transformation. To 'unlearn' existing behaviour and 'learn' new practices for a meaningful existence in a transformed system brings resistance. When individuals react to transformation in a political or social institution, their personal interests are usually at stake (Esterhuyse 2001:194-196). It was certainly the underlying issue when Heyns made his comment in 1994, but it is still very true according to the empirical studies. Members of the DR Church feel unsettled by social change, and if they do not find personal identity in new social discourses, they resist it. These feelings intensify with age.

The fact that different racial sections of the population were brought into closer contact after 1994 further complicated these reactions because it did not happen through spontaneous processes of interaction. Since 1994, African communalism, representing African cognitive and behavioural frames of reference, became noticeably dominant (Van der Walt 1999:25-26). Apartheid's negative effect on the collective black consciousness in South Africa (Du Toit 1999:8) led even more to African communalism being accentuated. The impendence for African communalism in a context where power and privileges previously beyond people's reach are gained is that a modern version of tribalism may appear where a new elite is favoured. It can defect into totalitarianism where the whole of society (with its economic, educational, political institutions) is organised in a single system of thought and power. This endangers democracy and marginalises those who do not identify with the system. In relation to this, De Klerk and Van Helden (2011:8) remark that many Afrikaners experience that the social set-up of late (with the government's system of affirmative action, black empowerment regulation and new racial discrimination which worsen relationships) has marginalised them. They do not have much of a choice but to accept these matters and are therefore negative and critical towards government and the social situation in South Africa. Nowadays, collective tension is deepening and social relationships are worsening and reaching far beyond the horizon of black and white ethnicity. Politicising the problems of the complex ethnic, cultural and economic integration in South Africa is to be blamed. These factors are definitely contributing to those initial reactions of collective social anxiety and insecurity prevailing.

The above discussion explains the reluctance amongst the members of the DR Church to accept the dominance of African communalism as social discourse. In addition, the legacy of criticism of the black freedom movement as well as 
the liberation theology - which also influenced the Dutch Reformed (DR) Church's daughter churches - towards the DR Church's civil religion contributed to this reluctance. More recently during 2014 and 2015, the DR Church went through a consultation and polling process about the acceptance of the Belhar Confession. This confession grew from the status confessionis which the DR Church's daughter church, the DR Mission Church (today Uniting Reformed Church in South Africa), declared in 1982 about the dire political and social situation as well as the DR Church's vindication of apartheid theology. The confession deals with reconciliation and justice in which God relates particularly to the poor and disadvantaged. The DR Church accepted this notion as a status accusationis et divisionis and ever since the Belhar Confession was not accepted in good faith. Although divided on this matter, the non-acceptance of the Belhar Confession in 2015 speaks loud and clear about the experiences of the DR Church's members at social root level. After two decades of political and social transformation, the effects of its history, as explained, still continue. According to the empirical research, members of the DR Church in urban areas are more tolerant towards South Africa's political system and cultural diversity, although it does not mean they embrace it altogether.

The year 1994 with its radical transformations also brought anomy to the DR Church in the sense that the church had lost its credibility and prophetic role in the country. The fact that the DR Church lost its prominent and privileged position in the South African society and also its ability to dictate public morals (Du Toit et al. 2002:3) only contributed to the awareness of anomy. Another contributing factor was the new Constitution of the Republic of South Africa, approved in 1996, which had brought about a distance between church and state.

The empirical research further disclosed that members of the DR Church are continuously reflecting on how their social environment affects their personal identities and lives. They also have an understanding of how social discourses in recent times brought about social changes and how these social changes affect their inherent vitality positively or negatively. Yet again, these reflections intensify with age. The research has also shown that members' religious experiences are not immune to the effects of social changes. This is true of the broader DR Church as was Heyns' observation in 1994. But it has not changed since because the DR Church past and present are deeply interwoven with its communities and the complexities of life in South Africa.

Interestingly, the outcome of the 2016 local government elections marks a distinctive change in the political scene of South Africa:

In its worst election outcome since the dawn of democracy, the ANC's electoral vote at the national level has declined from $62 \%$ to about 54\% between the 2011 and the 2016 local government elections. (Habib 2016:17)
'It's simply staggering that a party whose power and influence have been so thoroughly comprehensive has been evicted from all big metros except Durban and Bloemfontein' (Mthombothi 2016:17). But even if it indicates a new wave of social sentiments in reaction to the governance and shortcomings of the ANC-led government, the political and social situation of Afrikaners, as main members of the DR Church, may not change significantly in the foreseeable future.

In conclusion to this section then, the reactions described in this section may continue indefinitely. The DR Church has the responsibility to address the issues mentioned here in its members' lives but also has to raise the awareness of a more integrated and sensitive presence within our communities. The section The DR Church: Towards the 21st century deals with the integration of these issues into a hermeneutical framework for the church.

But it is not only the history of political and social transformation that has affected the DR Church. Smit (2001:120) refers to Piet Naude who postulates that changes in South Africa are not because of political processes only but also because of the influence of global cultural, economic and technological transformations. Thoughts on the history of these conjunctural events are next.

\section{The Dutch Reformed Church: In transition because of the history of global change}

Burger (2001:11) is of the opinion that political transformation in South Africa was inevitable, because of a new political dispensation. But changes caused by the influences of a global (post)modern, democratic, secular, free market and pluralistic society of which South Africa became part after years of isolation were something different. The DR Church was not prepared for the implications of these influences, which entail the following:

- The DR Church was directly impacted by structural secularisation, which changed its prominent position in the South African society dramatically. Secularisation as a social phenomenon separates any social order from religious influences (Turner 2011:128). Structural secularisation involves processes where public structures and institutions (scientific, educational, technological, judicial, etc.) are structurally separated from each other to exist in their own right without any reference to the numinous or ethics of religious nature (Taylor 2007:594). Through this differentiation process, the church as a social institution is increasingly alienated from the rest of the society and its influence is marginalised, leaving it with a message dogmatically depleted and ethically simplified (Norman 2003:15). South Africa today is no exception. Through structural secularisation, state governance, for example, maintains its neutrality towards religion and the influence of the church. 
Although the fibre of the South African populace is not completely secular, the DR Church lost its influence on politics and society in general through structural secularisation. This affects the credibility of the church. Some described it as the 'death' of the DR Church (Schreuder 2002:226). Some even anticipated it. The truth is that this crisis is more than just the DR Church's crisis. In general, religious frameworks are eroding in secularising societies (Turner 2011:140). According to the empirical outcomes, older DR Church members consider this development as unacceptable. Younger generations are less affected by the disintegration of relations between religious institutions and social institutions. Efforts to counter this disintegration are usually symbolic or even cosmetic

- In connection with the previous point, Du Toit et al. (2002:4) state that the enervation of the church causes the church and its members to be vulnerable to influences such as (social) secularisation, individuation and privatism, as well as moral liberalism. In addition, Durand (2002:53) argues that the implosion of the Afrikaner's theocratic tradition led to many members of the DR Church being indifferent towards the church and its mission. Instead, they are assimilated by South Africa's changing pluralistic context with its great deal of social secularisation. Social secularisation is a sociological phenomenon with two dimensions: secularisation of the public culture and secularisation of the personal conscience (Maclure \& Taylor 2011:21). At the public level, social secularisation is seen in the reduced social meaning of religion and its effect on public opinion (Avis 2003:52). The church's decrees in a secular context are seen as arbitrary or oppressing (Kirk 2002:122). Secularisation of the personal conscience can be described as the personal emancipation from the influence of a metaphysical world (Dekker 1997:133). Religion as source for personal wellbeing as well as religious instruction and directives dwindle. Instead, the individual focuses progressively on the actualisation of the self. This is particularly true of the Afrikaner after the end of apartheid. Nationalistic ideas of the Afrikaner middle class are increasingly displaced by materialism and consumerism (Czeglédy 2008:289). This was empirically confirmed: members of the DR Church, who are mainly Afrikaners, consider personal freedom, right to privacy, autonomy, freedom of choice and personal prosperity as important priorities. These priorities are the same irrespective of age or place of residency. For this reason, a type of solipsism also develops amongst modern Afrikaners whose involvement in social institutions, such as the institutionalised church, becomes more erratic.

Niemandt (2013b:9) states that South Africa experienced concentrated secularisation in a very short period of time after 1994. This has deeply affected the members of the DR Church, but it is also very prevalent amongst the growing black middle-class people who are becoming morally more liberated and materialistic in the search for personal benefit and thus contributing to the disintegration of group solidarity typical to the African spirit (Czeglédy
2008:289, 301). Secularisation brought another orientation to life in South Africa in general that cannot be resisted systematically (Norman 2003:50).

- Consequently, the ongoing processes of structural and social secularisation lead to the tendencies of social fragmentation, pluralisation and privatism. The weakening of absolute social discourses (such as political ideologies or religion) by structural and social secularisation creates the space for other social discourses to compete for social acceptance, hence fragmenting society (Martin 2005:2021). A sphere of uncertainty and relativism is hereby created (Avis 2003:69). Relativism causes 'truth' to become fluent and relevant only within a specific context (Kotze s.a.:72). It is clear that pluralisation as probable consequence furthers social fragmentation by accentuating and legitimising alternative discourses other than the dominant discourses. According to Norman (2003:36), the essence of social pluralism is the acceptance of different lifestyles, religious systems and values throughout society. As a result, diversity becomes the structuring principle of society impeding social cohesion on different levels of society (Maclure \& Taylor 2011:62). McGuire (1991:255) says that in reality pluralism undermines the credibility of all social discourses in a pluralistic society. In a pluralistic society, religious differentiation and multiplication occur, typically driven by subjective impulses and thus straining religious systems in the effort to sustain their orthodoxies (Maclure \& Taylor 2011:72). These subjective impulses lay the foundation for the privatisation of religion, localising it increasingly to the private spheres of society as a personal preference (Avis 2003:76), shifting it away from collective, traditional religion (Norris \& Ingelhart 2004:40). Privatised or individuated religion is usually syncretistic because it has to adapt to an individual's personal sentiments and his or her quest for personal well-being (Norman 2003:49). Personal values and morality are formed in the same pragmatic way putting collective religious and moral values under pressure (Avis 2003:94). Niemandt (2013b:9) argues that the reason the DR Church is losing members is because of the individuation of religion and the fact that people want to live independent lives. The empirical research confirms that for members of the DR Church the importance of religion is shifting to the private sphere. Even though the official church is still of importance to members of the church, their personal religion are less integrated with collective religious activities. Many members are of the opinion that religion is a personal matter. As a result, church-orientated religion loses its binding character by means of doctrine or decree. This happens more often in DR congregations in urban areas. It is clear that the church is institutionally deeply affected by its members' subjective convictions.

- Adding up the history of these developments, the DR Church certainly is in transition, transposing to something new as an institution. The outcome of that process is still unclear. Understandably, yet again, the emotions of anomy and resistance to change will accompany this 
process. In the DR Church's effort to accommodate change in the church and the different reactions to it, Oosthuizen (2012:3) mentions the metaphor of a big or spacious house. While striving for an ideal position, different opinions and practices have to be dealt with in a respectful manner in this big house. But in the meantime, the following factors are well at work transposing this big house:

- The changing relations of members to the DR Church as institution are acutely affecting the church. The empirical research has shown that many members do not consider church involvement at the institutional level as relevant for personal identity. Involvement at this level has become voluntary. With regard to this, Taylor (2007:482) makes it clear that the sense of community in the modern era has more to do with communal display where people gather for a specific course rather than a sense of deeprooted solidarity. Indifference to the institutional church leads to different levels of alienation that vary between nominal membership and total dechristianisation as the extreme. Oosthuizen (2013:1) is of the opinion that many people, having drifted away from the church, express their spirituality in other ways - something Dekker (1997:22) calls the phenomenon of post-religious faith. People consider themselves as spiritual but are totally indifferent to the institutional church.

- The compelling question to the church is what it should do in order to counter this detachment and alienation. Concerning the purpose and task of the church, it is clear that the spiritual needs and contexts of its members and people in general are factors to reckon with in order to minister effectively. These factors, as new structuring criteria for the ministry, can transpose the church to a type of service provider under pressure to satisfy by rendering appropriate service.

- As disclosed by the empirical research, DR Church members' personal spheres of religion are more important than the collective, institutionalised sphere of religion. Because of the focus on personal spiritual needs of members and because the authority of collective doctrine and beliefs diminishes, the DR Church is susceptible to new forms of spirituality or religiosities different to the dominant doctrine, beliefs and practices of the church. Steyn (2006:1-13) mentions the following religious constructs identifiable within the church: the reformed spirituality with its Calvinistic tradition, the rationalistic with its cognitive aspects, the charismatic with its emotional sentiments, the contemplative with its mystic inclination and the syncretistic referring to self-constructed religiosities that adapt, as was said, to an individual's personal sentiments. Nonetheless, personal choice and meeting members' spiritual needs become the determining factors in how they relate to the institutional church, either by supporting it or migrating from it. Larger congregations in urban areas are more open to new forms of spirituality and practices according to the empirical research. The direct result is internal pluralisation in those congregations. Age has a determining factor as well, because the younger members of the DR Church are more tolerant to different discourses and practices within the church. These discourses are consisting of selections of traditional doctrines and practices of the DR Church, elements from other church traditions and from popular religious literature and media. In these circumstances, the DR Church's reformed identity is jeopardised, especially in the lives of younger generations who identify less with it. These transposing effects on the DR Church are nearly unstoppable.

- Another factor transposing the DR Church as institution is congregationalistic tendencies. The contexts, needs and ministries of congregations differ. Durand (2002:61) states that there is a growing emphasis on the local congregation's independence from the broader church and presumes it is the secular world's influence. Considering secularisation's actions of fragmentation and pluralisation (as described), it is understandable that the local congregation may become uncommitted to the DR Church at large as constituted through its presbyteries and synods. Standardised communal confessionalism is therefore less likely to determine the local congregation's practices and liturgies. This tendency is accompanied by a growing reluctance to apply synodical decrees and resolutions. In reality, church members' thoughts on matters are diverse, congregations vary institutionally and even regional synods diverge from conformity regarding contested matters (Jansen van Rensburg 2007:11). The empirical research showed that less than a third of the respondents considered the resolutions of the church on contentious matters as binding to their conscience. Recent examples of the variation on matters are the controversy surrounding the possible acceptance of the Belhar Confession and the debate on homosexuality (more specific the ordination of gay clergymen and the sanctioning of same-sex marriages) that stirred up opposing reactions (Claasen 2016:6).

To end, it is clear that the factors described in this section decrease institutional stability and consequently the DR Church as a historic or mainstream church changes. The biggest challenge to its congregations is that they enter an era where they cannot rely on their uncompromised corporate and public presence or on traditional, institutionalised forms of religion and practices or on an unwavering devote collective to survive ad infinitum.

What the challenges described in this section, in addition to those described in the previous section, hold for the future of the DR Church is not easy to construct. Nevertheless, the following section aims at integrating these challenges into a hermeneutical framework to assist the praxis of the church. 


\section{The Dutch Reformed Church: Towards the 21st century}

Taylor (2007:745) suggests that in describing the history of Christianity, one ought to refrain from the idea that Christendom had lost its 'golden era'. The history of Christianity should instead be studied within Christianity's different contexts and within its different phases. Then the varied historical influences are realised. This applies to the DR Church as well. It also went through different phases because of the influences of different social and political contexts. What it would become as it moves on from its terminus transitus is not easily answered because of the manysidedness, as Snyman (2016:6) calls it, of the era we are living in. In these times, Snyman (2016:6) says people have a yearning for a many-sided church. From what has been said in this article, the following are constructed as a hermeneutical framework to fit a many-sided DR Church:

- First of all, the DR Church has to understand its members' experiences of social marginalisation which have led to self-imposed isolation from partaking in social and community affairs. It has impacted their relations with the church, although they do expect solidarity from the church they have been devoted to. The majority of respondents in the empirical research indicated the importance of the church in this regard. In affirming this need, the church has to show critical solidarity with the weal and woe of its members in the sense that the church also identifies and rectifies collective, social wrongdoing (Gaum 1981:36). But more importantly, the DR Church should find new ways of solidarity to bring people together to take up responsibility for what the second article of the church's constitution states. For this reason, the church cannot stop preaching about collective values and beliefs (Avis 2003:12). Otherwise, it would compromise on being a witness. In a secularising world, the church's focus on God is important (Snyman 2016:6). Christians have to bear witness of God's reality in which they believe (Hanekom 2011:8). The need to educate and equip members to give practical expression to their Christian beliefs becomes increasingly important (Cobb 1996:202). The DR Church has to help its members to clarify their own missio in which way their feelings of social marginalisation might be countered. Likewise, the importance of the contribution of the church's members to the survival of the church is accentuated (Louw 2010:18). Even though privatism may hinder these efforts, the DR Church does not have to quail in establishing its public presence in the South African society of today. In his report to the Highveld Synod in September 2014, Dr Gideon Kok reflects on the development of a missional church. He states that the future of the church lies within this position. The missional church understands the Missio Dei and reacts thereto by being witness to God's reconciliation and redemption within its own community. A missional church is not programme-driven but changes the local culture by its involvement in that context (Agenda Sinode Hoëveld 2014:180-181). During the same synodical meeting, a document reflecting on the prospects of the church in future-Gemeentewees in die Toekoms - was accepted. It is an excellent example of a comprehensive and practical guide for congregations on the development of inter alia missional ecclesiology and missional leadership. The document by Prof. Nelus Niemandt and Prof. Piet Meiring on a framework for the DR Church's missionality and calling, as accepted by the General Synod of the DR Church, is equally significant.

- Secondly, the transformation of the social and political set-up of South Africa has brought the DR Church to new horizons and inevitably into contact with other churches and religions. Differences in confession and association amongst Christians and churches often lead to hostility. This requires the DR Church to engage in talks with these churches but also to reflect on its own tradition and role in society (Niemandt 2013a:7). Taber (2002:191) refers to Schreiter who argues that cross-cultural dialogue discloses an ethnocentristic way of thinking in the church. The deconstruction of cultural presumptions occurs within this dialogue. In a positive sense, it creates space for mutual trust. This disclosure is a very important aspect in all cross-cultural dialogue in South Africa, not only for the DR Church but all other churches involved in dialogue, for example, the DR Church's dialogue within the DR family of churches as well as African Theology in which the DR Church lags behind. Price's (2002:111) remark highlights the necessity for this dialogue and mutual trust: 'White, Western, mainstream Christianity can no longer maintain that it is normative for all Christians'. In Protestantism, traditions are respected but it must be remembered that absolute wisdom and insight have never been isolated to only one tradition or era (Stackhouse 1995:40). Along the road of dialogue and mutual trust, the possibility of ecumenism comes to pass so that the church at large can be a 'community of communities' (Aleaz 2002:168). In the ecumenical community, a plurality of identities is accepted within a hermeneutical context in an effort to comprehend the role of sociopolitical, religious and cultural realities in people's lives (Aleaz 2002:170). A many-sided church ought to be engaged in public debate about the issues of its surrounding world and tangibly lend a helping hand to the vulnerable (Snyman 2016:6).

Article 70 and Regulation 22 of the DR Church's constitution arrange and formalise its ecumenical relations. On the national level, the DR Church has ecumenical relations through the South African Council of Churches and The Evangelical Alliance of South Africa. It serves as a member of the National Religious Leaders' Forum where, together with major Christian churches and leaders of other religious groups, issues concerning the welfare of the country are discussed and mediated with government. Globally, the DR Church has ecumenical ties with the World Communion of Reformed Churches and the World Council of Churches of which it became a member again in June 2016 since its termination of membership in 1960. 
- Thirdly, the DR Church is changing. However, it is constantly transforming into an open system. The proliferation of alternative forms of spirituality (because of expressive individualism and privatism) that develops independent of formal decree and standardised, collective beliefs occur particularly in larger congregations in more heterogeneous environments. This has implications for the church's identity. To manage the diversity of change within the church, it has to become an 'adaptable church', as Niemandt (2011:13) refers to the idea of Thomas Bandy. The empirical research made it clear that members of the church are fairly tolerant to changes within the church, provided that the familiar religious system of beliefs is not imperilled.

Reformed churches' decrees and confessions form their identity. In a time where denominational identities are under pressure, the DR Church has to consider what its identity entails (Van Rensburg 2010:21). To rethink the DR Church's identity for the 21st century, it is important to have historical insight and awareness of the development of spirituality (Hofmeyr 2009:604).

When considering the reformed identity of the DR Church, it is not only about specific religious constructs but rather comprises the following religious motives (Burger 2001:48 referring to Brian Gerrish):

- The notion of Coram Deo - a life before God wherein God is central to the existence of the church and the faithful.

- The Word of God as absolute authority for life.

- A reformed way of life asks for biblical integrity. Every reformed Christian knows that Christ saves through grace and accepts that in faith (Du Toit et al. 2002:5).

- An effort to understand the complexity of life and to engage with it.

The DR Church was also influenced by evangelicalism during the 19th century through the Reveil in the Netherlands, in particular that movement's reformed pietism that emphasises the need for and the fruit of repentance, as well as the work of the Holy Spirit (Du Toit et al. 2002:11).

Bound to these deeply rooted motives, the DR Church has to formulate what it believes and what its calling is. This is not an easy task because differences exist within the DR Church concerning the interpretation and authority of Scripture as well as its confessions and decrees. However, any church or academic theology pursued to constructively counteract unregulated and random spiritual or religious expressions within the DR Church ought to consider the following parameters: reformed theology is theocentric; reformed theology is Scriptural and endeavours responsible hermeneutics; reformed theology is confessional by formally affirming religious convictions and reformed theology is contextual because through its reflection on current issues it seeks to establish a relevant ecclesiology and ethical framework (Du Toit et al. 2002:243; Van Wyk 2008:1075).
The most recent declaration of the DR Church on its calling in the current South African context is that of the General Synod of 14 October 2011. By means of this declaration, the church constitutes its presence in the South African society. Consequently, the church inter alia:

- calls on its congregations to be transformed by God's Word and Spirit into upright witnesses

- reaches out to other faith communities and establishes unity without compromising its own reformed identity

- supports all efforts to sustain our democratic values and human rights and strives for reconciliation and justice

- acknowledges the mission to transform the texture of society.

- Lastly, the DR Church is in transition towards the 21st century. Does that have any implication for theology as academic discipline within the bosom of the church? The following aspects are relevant against the backdrop of this article:

- An ever-changing society sets theological studies in constant motion as Du Toit (2007:35) writes: '... [We] should perhaps speak of a new game. We have reached the end of modern, patriarchalist, metaphysically closed, identity theology'. Within the DR Church, theological shifts also occurred. This is surely what Botes (2016:13) has in mind when he voices his concern that none of the three theological faculties at Stellenbosch, Bloemfontein and Pretoria are Dutch Reformed or reformed anymore. According to the empirical research, many members of the DR Church apparently have the perception that the credibility of theology as academic discipline is under pressure because the outcomes of modern, rational cognitive frameworks are increasingly influencing the process of theologising. To clear this matter, we have to consider what Küng (1989:29-30) has to say about paradigm shifts in theology. No paradigm shift is complete in every respect. There are continuity and discontinuity, rationality and irrationality, conceptual stability and conceptual change, and evolutionary and revolutionary elements between successive paradigms rather than total schism. The option for an absolutistic or relativistic position is almost excluded.

One thing is for sure and that is that particularistic thought is increasingly isolated. The predicament is rather that because of particular contextual (past and present) influences, the issue of pluralism arises in theology as academic discipline. Thus, Brauer (1989:207) argues that because of varied interpretations of basic Christian conceptions, theology has to be open to the idea of integrated diversity. Hence, history and the present have to be considered in the process of theologising because theological ideas at a specific time are only versions of the dominant dogma of the church at that time (Gerrish 1989:163). In reality, it is complicated to integrate diversity. With reference to the recent debate 
on the DR General Synod's resolution on the issue of homosexuality, Venter (2016:11) writes that the effort of the General Synod to accommodate hermeneutical differences has been a defining moment. The views regarding the authority and infallibility of Scripture, the conversation on truth and reality between religion and science as well as the historical and dogmatic identity of the DR Church are yet again complicating the task of theology to integrate diversity.

- Furthermore, academic theologians have the task to co-operate in creating an overarching context where the Christian faith can add to the comprehensive understanding of reality (Cobb 1996:198). During the Johan Heyns memorial lecture of 2016 at the University of Pretoria, Prof. Wentzel van Huyssteen in this regard remarked on the role of interdisciplinary systematic thought in addressing existential issues. Theology has to come together with other social and natural sciences within a cultural and intellectual context in which the influences of the specific location, time and linguistic framework are reflected. Consequently, it becomes a public theology (Veldsman 2016:20). Public theology is of utmost importance because the present-day world is pragmatic according to Koopman (2003:6). Regarding today's collective reality, public theology should contribute to the public discourses on morality for instance. Structural secularisation and institutional differentiation can reduce the input of public theology to only an academic effort with no social impact whatsoever.

But, as Heinrich Bedford-Strohm argued during his public lecture on 31 July 2006 at the University of Pretoria, public theology must have an ecumenical and social response to the effects of globalisation, including secularisation. In that response, public theology has to use the frameworks the secular world comprehends, without compromising its own theological foundations. Through the insights of Christian realism, the ecumenical church should see what the world has become and what it should be in Christ. And then it should strive to manifest people's worth as God's creations (Bedford-Strohm 2006:1113). Within the South African context, this effort should be all the more ecumenical. Co-operation with those churches representing African communalism should be brought about so that an ecumenical theology can collaborate in the establishment and domestication of values and morals relevant to the South African society at large. In this sense, Du Toit (2007:27) remarks on the importance of an African theological identity that ought to contribute to a Christian value system relevant to Africa.

\section{Conclusion}

This article was an inquiry into the contextual and religious situation of the Dutch Reformed Church since 1994, its terminus transitus. Different phenomena, of which some have a historical genesis and others a sociological, are at work in transforming the church to an institution presently facing the following challenges on how to:

- show critical solidarity with its members without becoming a sympathiser to the cause of the Afrikaner exclusively

- expel its members' experiences of anomy and collective anxiety amidst challenging political and economic times

- create awareness amongst its members to have an integrated and sensitive presence through their charitableness and witnessing, although they are increasingly focused on their private spheres

- restore its credibility as institution by advocating moral values in a world where its impact has been decreasing

- advance collective systems of faith and involvement amongst members whose involvement has become erratic because of privatisation and some degree of alienation

- preserve its historical identity despite growing religious pluralism and deconfessionalisation in its midst

- engage in meaningful ecumenical relations to contribute in addressing public issues

- assist its theological enterprises to be relevant to the church and society at large.

What the DR Church will become on its way towards the 21st century depends on how it responds to the challenges described in this article.

\section{Acknowledgements Competing interests}

The authors declare that they have no financial or personal relationships that may have inappropriately influenced them in writing this article.

\section{Authors' contributions}

P.K. wrote and prepared the article. J.M.v.d.M. provided supervision (for PhD studies as well as following articles).

\section{References}

Agenda vir die een-en-twintigste vergadering van die Sinode Hoëveld van die Nederduitse Gereformeerde Kerk in Kemptonpark, 9-11 September 2014, 'Strategiese fokusarea: Ontwikkeling van 'n missionale kerk', Portefeuljeleier: Dr GJ Kok. pp. 180-204.

Aleaz, K.P., 2002, 'The globalization of poverty and the exploitation of the Gospel', in T.F. Foust, G.R. Hunsberger, J.A. Kirk \& W. Ustorf (eds.), A scandalous prophet. The way of mission after Newbigin, pp. 165-173, Eerdmans Publishing Co., Grand Rapids, MI.

Avis, P., 2003, A church drawing near. Spirituality and mission in a post-Christian culture, T\&T Clark International, London.

Bedford-Strohm, H., 2006, Public theology and the global economy. Ecumenical social thinking between fundamental criticism and reform, Public lecture at the Faculty of Theology, University of Pretoria, Pretoria, 16 p. (Unpublished.)

Botes, D., 2016, 'Hoe dink ons oor die wet en die liefde? Die kruis kan nie verstaan word sonder die wet nie', Kerkbode, June 3, p. 13.

Brauer, J., 1989, 'A paradigm for theology? Introductory remarks', in H. Küng \& D. Tracy (eds.), Paradigm change in theology - A symposium for the future, pp. 205-211, The Crossroad Publishing Company, New York.

Burger, C., 2001, Ons weet aan wie ons behoort. Nuut gedink oor ons gereformeerde tradisie, Lux Verbi.BM, Wellington.

Claasen, G., 2016, 'Ons moet die eenheid koester', Kerkbode, July 22, p. 6.

Cobb, J.B., jnr., 1996, 'The multifaceted future of theology', in M. Volf, C. Krieg \& T. Kucharz (eds.), The future of theology, pp. 196-204, Eerdmans Publishing Co., Grand Rapids, MI. 
Cody, R.P. \& Smith, J.K., 2006, Applied Statistics and the SAS programming language, 5 th edn., Pearson Prentice Hall, Upper Saddle River, NJ.

Czeglédy, A.P., 2008, 'A new Christianity for a New South Africa: Charismatic Christians and the post-apartheid order', Journal of Religion in Africa 38(3), 284-311. https://doi.org/10.1163/157006608X323504

Dekker, G., 1997, Godsdienst en samenleving: Inleiding tot de studie van de godsdienstsociologie, 4de druk, Uitgeverij Kok, Kampen.

De Klerk, B. \& Van Helden, P., 2011, 'Oorsake van kerkkrimping binne die tradisioneel Afrikaanssprekende gereformeerde kerke in Suid-Afrika', Verbum et Ecclesia 32(1), 1-10. https://doi.org/10.4102/ve.v32i1.477

Die Kerkorde van die Nederduitse Gereformeerde Kerk, 2015, Algemene Taakspan Regte van die Algemene Sinode.

Durand, J., 2002, Ontluisterde wêreld: Die Afrikaner en sy kerk in 'n veranderde SuidAfrika, Lux Verbi.BM, Wellington.

Du Toit, C., 1999, 'The quest for African identity and the concept of nation-building as motives in the reconstruction of South African society', in T.G. Walsh \& F. Kaufmann (eds.), Religion and social transformation in South Africa, pp. 1-23, Paragon House, St Paul, MN.

Du Toit, C.W., 2007, Seasons in theology. Inroads of postmodernism, reference and representation, Research Institute for Theology and Religion, UNISA, Pretoria.

Du Toit, P.R., Hofmeyr, J.W., Strauss, P.J. \& Van der Merwe, J.M., 2002, Moeisame pad na vernuwing. Die NG Kerk se pad van isolasie en die soeke na 'n nuwe relevansie, Barnabas, Bloemfontein.

Esterhuyse, W.P., 2001, 'Before the next rains: From apartheid to transformation', in J.W. Hofmeyr, C.J.S. Lombaard \& P.J. Maritz (eds.), Perspectives on Christianity: 1948 plus fifty years. Theology, apartheid and church: Past, present and future, pp. 187-200, Series 5, vol. 1, Institute for Missiological and Ecumenical Research, Pretoria.

Gaum, F.M., 1981, Die kerk en die toekoms van Suid-Afrika, NG Kerkboekhandel Transvaal, Pretoria.

Gerrish, B., 1989, 'From 'Dogmatik' to 'Glaubenslehre': A paradigm change in modern theology?', in H. Küng \& D. Tracy (eds.), Paradigm change in theology A symposium for the future, pp. 161-173, The Crossroad Publishing Company, A symposium

Habib, A., 2016, 'Election setback proves that Zuma's scandals do matter', Sunday Times, August 7, p. 17

Handelinge van die negende Algemene Sinode van die Nederduitse Gereformeerde Kerk in Pretoria, 11-20 Oktober 1994, 'Broederlike onderhoud. Uitdagings van die Nuwe Suid-Afrika vir die Ned Geref Kerk', J.A. Heyns, pp. 530-535.

Hanekom, B., 2011, 'As 'n kerk hoop verloor', Kerkbode, August 5, p. 8.

Heuvel, M.C., 1999, Rebuilding our nation - Participating in the political process from the perspective of a Biblical Christian worldview, Series F2, Brochures of the the perspective of a Biblical Christian worldview, Series
Institute for Reformational Studies, p. 71, Potchefstroom.

Hofmeyr, J.W., 2009, 'Spiritualiteit in die NG Kerk van die 21ste eeu teen die agtergrond van Calvyn en die Nadere Reformasie', NGTT 50(3\&4), 595-605.

Jansen van Rensburg, N., 2007, 'Diversiteit en diskresie merk nou die NG Kerk', Kruisgewys 7(2), 10-11.

Kirk, J.A., 2002, 'Mission in the West: On the calling of the Church in a postmodern age', in T.F. Foust, G.R. Hunsberger, J.A. Kirk \& W. Ustorf (eds.), A scandalous prophet. The way of mission after Newbigin, pp. 115-127, Eerdmans Publishing Co., Grand Rapids, MI.

Kotze, J.C.G., s.a. (sine anno), Die kerk op sy soektog - die verkenning, NG Kerkuitgewers, Kaapstad.

Koopman, N., 2003, 'Some comments on public theology today', Journal of Theology for Southern Africa 117, 3-19.

Küng, H., 1989, 'Paradigm change in theology: A proposal for discussion', in H. Küng \& D. Tracy (eds.), Paradigm change in theology $-A$ symposium for the future, pp. D. Tracy (eds.), Paradigm change in theology - A sy
3-33, The Crossroad Publishing Company, New York.

Louw, L., 2010, 'Het die toekoms 'n kerk?', Kerkbode, May 21, p. 18
Maclure, J. \& Taylor, C., 2011, Secularism and freedom of conscience, Harvard University Press, Cambridge, MA.

Martin, D., 2005, On secularization: Towards a revised general theory, Ashgate, Aldershot.

McGuire, M.D., 1991, Religion: The social context, 3rd edn., Wadsworth Publishing Company, Belmont, CA

Moltmann, J., 1989, 'The interlaced times of history: Some necessary differentiations and limitations of history as concept', in H. Küng \& D. Tracy (eds.), Paradigm change in theology - A symposium for the future, pp. 320-339, The Crossroad Publishing Company, New York.

Mthombothi, B., 2016, 'ANC's swagger becomes a limp', Sunday Times, August 7, p. 17. Niemandt, N., 2011, 'Aanpasbare kerk', Kruisgewys 11(3), 13.

Niemandt, N., 2013a, '“Ons” en "hulle": 'n nuwe moontlikheid', Kerkbode, January 18, p. 7.

Niemandt, N., 2013b, 'Die NG Kerk krimp: Waar moet ons die redes soek?', Kerkbode, February 1, p. 9.

Norman, E.R., 2003, Secularisation: Sacred values in a secular world, Continuum, London.

Norris, P. \& Inglehart, R., 2004, Sacred and secular: Religion and politics worldwide, Cambridge University Press, Cambridge.

Oosthuizen, J., 2012, 'Kleiner maar ruimer NG Kerk', Kerkbode, March 16, p. 3.

Oosthuizen, J., 2013, 'Krimpende kerk nie net sleg', Kerkbode, January 18, p. 1.

Price, L., 2002, 'Churches and postmodernity: Opportunity for an attitude shift', in T.F. Foust, G.R. Hunsberger, J.A. Kirk \& W. Ustorf (eds.), A scandalous prophet. The way of mission after Newbigin, pp. 107-114, Eerdmans Publishing Co., Grand Rapids, Ml.

Schreuder, N., 2002 '1994. Toekomsskok of toekomsvisie?', in G. Hofmeyr (red.), NG Kerk 350 - Eenhonderd bakens in die geskiedenis van die Nederduitse Gereformeerde Kerk 1652-2002, pp. 226-227, Lux Verbi.BM, Wellington.

Snyman, S.D., 2016, 'Gevra: 'n veelkantige kerk', Kerkbode, June 03, p. 6.

Smit, D.J., 2001, 'Has there been any change? On the role of the Dutch Reformed Church 1974-1990', Scriptura 76, 119-126.

Stackhouse, M.L., 1995, 'Christian social ethics in a global era: Reforming Protestant views', in M.L. Stackhouse (ed.), Christian social ethics in a global, pp. 11-73, Abingdon Press, Nashville, TN.

Steyn, G.J., 2006, 'Die NG Kerk se identiteitskrisis. Deel 2: Huidige bewegings, tendense of mutasies', 30 September, email to: Kruger, P., pkkruger@telkomsa.net

Taber, C.R., 2002, 'The Gospel as authentic meta-narrative', in T.F. Foust, G.R. Hunsberger, J.A. Kirk \& W. Ustorf (eds.), A scandalous prophet. The way of mission after Newbigin, pp. 182-194, Eerdmans Publishing Co., Grand Rapids, MI.

Taylor, C., 2007, A secular age, Harvard University Press, Cambridge, MA.

Turner, B.S., 2011, Religion and modern society. Citizenship, secularisation and the state, Cambridge University Press, Cambridge.

Van der Walt, B.J., 1999, Godsdiens en samelewing - Christelike betrokkenheid op die markplein, s.n. (sine nomine), Potchefstroom. (Reeks F3: Versamelwerke van die Instituut vir Reformatoriese Studie, 1999:51).

Van der Watt, P.B., 1989, Die Nederduitse Gereformeerde Kerk 1652-1905, NG Kerkboekhandel, Pretoria.

Van Wyk, J.H., 2008, 'Gereformeerde teologie', in F. Gaum (ed.), Christelike Kernensiklopedie, p. 1075, LuxVerbi.BM, Wellington.

Veldsman, D., 2016, 'Van Huyssteen: Só pak die teologie probleme aan', Kerkbode, June 17, p. 20.

Venter, D., 2016, 'Hoe lees ons die Bybel?', Kerkbode, February 05, p. 11.

Wessels, A., 2001, 'Die oorlog se bose kringloop', in F. Pretorius (red.), Verskroeide aarde, pp. 254-257, Human \& Rousseau (Edms.) Bpk., Kaapstad. 